УДК 336.717 .122

CERIF: S144

\author{
Др Мирјана Радовић, LL.M. (Humboldt)
}

\title{
ОПОЗИВ ЧЕКА
}

У овом раду ауторка истражује правне аспекте опозива чека. Први део рада објашњава појам, правни значај и правну природу опозивања чека. Други део је посвећен праву на опозив чека и условима за његово вршење. У том погледу је анализиран утицај протека рока за презентаџију чека на исплату, извршена исплате чека од стране банке трасата, као и прихватања самосталне обавезе банке трасата према имаоуу чека, на право трасанта да опозове пуноважно издат чек. Потом су објашњене основне карактеристике изјаве о опозиву чека, које се тичу: даваоиа, адресата, форме, садржине и пријема изјаве, односно момента наступања юених правних дејстава. Следећи део се бави упоредноправном праксом ограничавана рока важења опозива чека и утврђивањем њене прихватљивости у српским оквирима. Најзад, у последњем делу је пружена детаљна анализа правних последица пуноважног опозива чека, пре свега из угла права и обавеза банке трасата.

Кључне речи: Опозив. - Чек. - Платни налог. - Текући рачун. - Прејудициparbe.

\section{1. УВОД}

Чек по својим основним карактеристикама и начину регулисања показује изразите сличности с меницом, због чега се у правној теорији често дефинише као специјализована трасирана меница. ${ }^{1}$ Упркос томе, чек је у односу на меницу по много чему специфичан, што оправдава његово издвајање у посебну врсту новчане хартије од

* Ауторка је доценткиња Правног факултета Универзитета у Београду, mirjanam@ius.bg.ac.rs

1 Такво дефинисање потиче из енглеског права, где чек представља меницу вучену на банку и плативу по виђењу. Вид. Peter Ellinger, Eva Lomnicka, Christopher Hare, Ellinger's Modern Banking Law, Oxford 20115 , 398; Ross Cranston, Principles of Banking Law, Oxford $2005^{2}, 258$. 
вредности. Једну од особености чека у поређењу с меницом управо чини институт опозива чека. ${ }^{2}$ Овај правни институт није нов у српском праву, будући да је на исти начин уређен још од усвајања Закона о чеку из 1946. године. ${ }^{3}$ Штавише, опозив чека није ни правнополитички актуелна тема, имајући у виду да се о његовим регулаторним изменама тренутно уопште не размишља. Ипак, без обзира на описано стање дуготрајне примене истоветних правних норми о опозиву чека у српској пракси, продубљено истраживање опозива чека у српској правној науци изостаје. Отуда је циљ овог рада да пружи детаљну правну анализу опозива чека, пре свега ослањањем на богату правну теорију и праксу развијених земаља, како би се омогућило критичко преиспитивање квалитета и домашаја правног уређења и схватања овог института у праву Србије.

\section{2. ПОЈАМ И ПРАВНИ ЗНАЧАЈ ОПОЗИВА ЧЕКА}

Под опозивом чека (енгл. countermand, stopping payment of a cheque, нем. Scheckwiderruf, Schecksperre, франц. révocation du chèque) се подразумева изјава воље, којом ималац текућег рачуна (трасант) захтева од банке, која води текући рачун (трасата) да не изврши исплату одређеног пуноважно издатог чека. ${ }^{4}$ Из наведеног појма произлази да се опозив чека тиче искључиво односа између банке трасата и издаваоца чека (имаоца текућег рачуна). ${ }^{5}$ У овом односу банка унапред преузима обавезу према имаоцу текућег рачуна да ће под уговореним условима на захтев законитог имаоца исплатити чек, који је ималац рачуна издао и вукао на њу, уз право да трошкове такве исплате накнади задужењем текућег рачуна издаваоца. ${ }^{6}$ Према томе, чек представља унапред уговорени начин на који ималац текућег рачуна може да да̂ платни налог на терет свог рачуна банци која води текући

2 Мирко С. Васиљевић, Трговинско право, Београд $2014^{14}, 518$.

3 Закон о чеку - ЗЧ, Службени лист ФНРЈ, бр. 105/46, Службени лист СФРЈ, бр. 12/65, 50/71, 52/73, Службени лист СРЈ, бр. 46/96, Службени лист СЦГ, бр. $1 / 2003$.

4 Michael Hakenberg, Ebenroth/Boujong/Joost/Strohn-Handelsgesetzbuch: Band 2 - $\S$ 343-475h: Transportrecht, Bank- und Börsenrecht (Hrsg. D. Joost, L. Strohn), München 2015, 1689; Ивица Јанковец, Привредно право, Београд 19994, 734.

5 Милан Бартош, Зоран Антонијевић, Владимир Јовановић, Менично и чековно право, Београд 1974, 233.

6 Stefan Werner, Bank- und Kapitalmarktrecht (Hrsg. S. Kümpel, A. Wittig), Köln 20114 , 1018; упор.: J. H. de V. Dijkman, „Countermand of a Certified Cheque“, The South African Law Journal Vol. 105, 1988, 83; Ronald J. Mann, Payment Systems and Other Financial Trasactions: Cases, Materials, and Problems, Gaithersburg - New York $2003^{2}, 9$ и 10. 
рачун. У том смислу је он врста платног инструмента. ${ }^{7}$ Закључује се да у односу између банке трасата и трасанта чек није само хартија од вредности, већ у себи садржи и платни налог трасанта, који је банка под уговореним условима обавезна да изврши, уз право на покриће трошкова из средстава на његовом одређеном текућем рачуну.

Наведени платни налог трасанта, који је дат путем чека и који законити ималац презентацијом чека на исплату као курир доставља банци трасату, чини предмет опозива код чека. Дакле, опозив чека је усмерен ка опозивању (спречавању извршења) платног налога трасанта упућеног банци трасату путем овог платног инструмента. ${ }^{8}$ Стога, поједини домаћи аутори исправно указују на чињеницу да овде заправо не долази до опозива самог чека. ${ }^{9}$ Другим речима, чек као хартија од вредности постоји независно од опозива, будући да опозив утиче искључиво на платни налог у чеку, али не и на права законитог имаоца према издаваоцу чека и евентуалним другим регресним чековним дужницима. ${ }^{10}$ Међутим, у одређеним ситуацијама опозив платног налога датог путем чека ипак води опозиву читавог чека. Реч је о ситуацији када је опозив учињен након протека крајњег рока за презентацију чека на исплату.

Од момента протека рока за презентацију на исплату чек губи својство хартије од вредности, с обзиром на то да тада услед прејудицирања престају сви регресни чековни захтеви, који су уједно и једини правни захтеви законитог имаоца по основу чека. Отуда се прејудициран чек своди на платни налог трасанта према трасату, јер свом имаоцу не даје никакав правни захтев, већ представља искључиво легитимациони папир помоћу кога он остварује наплату. Имајући у виду да прејудициран чек као легитимациони папир још једино важи као платни налог трасанта упућен банци трасату, опозивањем овог налога долази до опозива читавог чека, ${ }^{11}$ који након тога више не производи никаква правна дејства. Сходно томе, када је прејудициран чек опозван, престаје обавеза банке трасата према трасанту да исплати чековну своту његовом имаоцу, захваљујући чему такав чек надаље има својство обичне доказне исправе, коју ималац може да користи као доказ у евентуалном спору из основног посла против издаваоца, односно преносиоца.

7 Упор. R. Cranston, 258; E. P. Ellinger, E. Lomnicka, C. V. M. Hare, 488.

8 Franz Häuser, Münchener Kommentar zum Handelsgesetzbuch - Band 6: Bankvertragsrecht (Hrsg. K. Schmidt), München 2014³, 460.

9 М. Бартош, 3. Антонијевић, В. Јовановић, 233.

10 Упор. J. Reynolds, „Countermand of Cheques“, U. B. C. Law Review Vol. 15, No. 2, 1981, 366.

11 Упор. М. Бартош, З. Антонијевић, В. Јовановић, 233. 
С обзиром на то да се опозив чека односи на спречавање извршења платног налога, који трасант путем овог платног инструмента даје банци трасату, он може да постоји само ако је чек пуноважно издат, тако да заиста садржи пуноважан платни налог имаоца текућег рачуна. У супротном, ако у оквиру чека није дат пуноважан платни налог имаоца текућег рачуна (на пример, због злоупотребе, односно фалсификовања чека), такав чек не може да се опозове, jep не постоји налог који би био основ за исплату од стране банке трасата и следствено задужење клијентовог текућег рачуна. ${ }^{12}$ Из тог разлога, када ималац текућег рачуна обавести банку да су му украдени чековни формулари, таква изјава нема природу опозива чека, већ представља само обавештавање банке, којим се она упозорава на предстојећу потенцијалну злоупотребу фалсификовањем клијентових платних налога коришћењем овог платног инструмента. ${ }^{13}$

\section{3. ПРАВНА ПРИРОДА ОПОЗИВА ЧЕКА}

Правна природа опозива чека је у упоредноправној теорији спорна, док у српском праву још увек није озбиљније разматрана. У том погледу су могућа два супротстављена схватања. С једне стране, опозив чека се третира као једнострана изјава воље трасанта упућена банци трасату, којом се накнадно одузимају правна дејства платног налога датог путем чека. Према томе, по овом схватању опозив чека представља опозив претходно пуноважно дате изјаве воље - платног налога трасанта. С друге стране, опозив чека може да се тумачи и као противналог, којим трасант забрањује банци трасату да исплати пуноважно издат чек. ${ }^{14}$ У складу с овим схватањем, опозивањем чека трасант налаже банци трасату да не изврши платни налог, који је он претходно, пуноважно дао путем чека. Иако се наведена различита схватања на први поглед чине само теоријски занимљивим, она су и изразито практично релевантна.

Када се опозив чека квалификује као одузимање правних дејстава трасантовој изјави воље, платни налог је након пуноважног опозива дефинитивно угашен и више ни под којим условима не би могао да „оживи“, односно да поново почне да производи правна дејства. За разлику од тога, када се опозив посматра само као противналог, који је обрнут у односу на претходно дати налог, онда као и сваки други налог може да има ограничен рок трајања. У том року

12 Gerd Nobbe, Bankrechts-Handbuch - Band I (Hrsg. H. Schimansky, H.-J. Bunte, H.-J. Lwowski), München $2011^{4}, 1680$.

13 Упор. Cédric Alter, Droit bancaire général, Bruxelles 2010, 329.

14 Stefanie Fandel, Handbuch des Fachanwalts: Bank- und Kapitalmarktrecht (Hrsg.P. Н. Assies et al.), Köln 2015², 326; F. Häuser, 461; М. С. Васиљевић, 518. 
банка трасат би била дужна да поступи у складу с опозивом, те да одбије исплату чека имаоцу, док би након његовог истека забрана исплате чека престала да важи, тако да би банка трасат поново имала право и обавезу поступања у складу с првобитно датим платним налогом из чека.

У праву Немачке и САД преовлађује другонаведено схватање, по коме се опозив чека третира као противналог. Насупрот томе, у српском праву ни законодавац, а ни правна теорија нису пружили недвосмислен одговор на ово питање. Имајући у виду важећу законску терминологију и уређење правних последица опозива, чини се да више аргумената говори у прилог схватању опозива чека као опозива платног налога трасанта, а не само као противналога. Такав закључак произлази из употребе израза „опозивање“, као и непостојања прописаног временског ограничења једном учињеног опозива у Закону о чеку. ${ }^{15}$ Ипак, поједини српски аутори наглашавају да је опозив чека противналог трасанта, ${ }^{16}$ додуше, без ближег појашњења разлога и последица прихватања таквог становишта.

\section{4. ПРАВО НА ОПОЗИВ ЧЕКА}

Право трасанта да опозове пуноважно издат чек је утемељено у самом закону. Стога, иако уговор између банке трасата и трасанта (имаоца текућег рачуна) често предвиђа одређена ограничења у његовом вршењу, право на опозив чека не може да буде укинуто на уговорној основи. ${ }^{17}$ Штавише, право трасанта да опозове чек постоји без обзира на разлог и независно од навођења разлога за опозив. Оно се не доводи у питање, упркос томе што старање о примени датог опозива и строге правне последице његовог непоштовања представљају оптерећење и могу да изазову потешкоће у редовном пословању банке. ${ }^{18}$

Начелно, трасант има право да опозове чек само ако су испуњени одређени услови, који се тичу: 4.1. протека рока за презентацију чека на исплату; 4.2. неизвршења исплате чека; и 4.3. непостојања самосталне обавезе банке трасата да исплати чек законитом имаоцу.

15 ЗЧ, чЛ. 15.

16 М. С. Васиљевић, 518.

17 Hans-Peter Schwintowski, Bankrecht, Köln 2011³, 339; упор. Е. P. Ellinger, Е. Lomnicka, C. V. M. Hare, 488.

18 Rafael Herrera, „Computerized Check Processing De Minimis Errors in Check Description on Stop Payment Orders“, Computer/Law Journal Vol. IX, 1989, 206; упор.: Sandra Rodgers Magnet, „Inaccurate or Ambiguous Countermand and Payment over Countermand“", Canadian Business Law Journal Vol. 4, 1979/80, 308. 


\section{1. Значај протека рока за презентацију чека на исплату за вршење права на опозив чека}

Према основном правилу Закона о чеку, опозив чека производи правна дејства након протека рока за његову презентацију на исплату. ${ }^{19}$ То, другим речима, значи да тек од тог момента банка трасат има обавезу према трасанту да поступи у складу са опозивом, те да одбије исплату чека законитом имаоцу. У правној теорији се као оправдање за изложено правило истиче да оно убрзава циркулацију чека, подстичући законитог имаоца да га презентује банци трасату у року за исплату, јер ће у супротном бити изложен ризику опозива. ${ }^{20}$ Осим тога, допуштањем опозива чека тек након протека рока за презентацију на исплату се штити и поверење законитог имаоца у правни привид да у основи издавања чека постоји пуноважан платни налог између трасанта и банке трасата, који је извршив барем до истека крајњег рока за презентацију, ако не и дуже - захваљујући неопозивању или каснијем опозиву. ${ }^{21}$

Поставља се питање, због чега уопште постоји потреба да се чек опозове након протека рока за презентацију на исплату. Од овог момента чек је прејудициран, што значи да престају права законитог имаоца према свим регресним чековним дужницима, укључујући и трасанта. Међутим, чек и надаље представља пуноважан платни налог трасанта упућен банци трасату посредством његовог имаоца. Отуда, све док тај платни налог не буде опозван, банка трасат има право и обавезу да га изврши на терет текућег рачуна издаваоца. ${ }^{22}$ Штавише, правна дејства платног налога датог путем чека су у српском праву временски неограничена. Следствено томе, банка трасат би у односу на трасанта била дужна да исплати чек, који јој ималац поднесе на исплату у било ком тренутку, све до затварања текућег рачуна - што теоријски може да буде и тридесет година од датума његовог издавања. Из изложеног произлази да протек рока за презентацију на исплату чека није релевантан за правни однос између трасанта и банке трасата, будући да независно од тога банку терети истоветна обавеза према имаоцу текућег рачуна да изврши исплату лицу, које се легитимише путем чека, из покрића на датом текућем рачуну.

Од начелног правила да чек може пуноважно да се опозове тек након протека рока за презентацију на исплату постоје два изузетка.

\footnotetext{
19 Упор. С. Alter, 330.

20 Овај аргумент је био присутан у ранијем немачком праву. Вид.: F. Häuser, 461.

21 Упор. C. Alter, 328 и 329, који ово правило објашњава гаранцијом трасанта према законитом имаоцу.

22 Упор. M. Hakenberg, 1689; G. Nobbe, 1678.
} 
$\mathrm{C}$ једне стране, српски Закон о чеку изричито прописује да је банка трасат дужна да поштује опозив чека и пре прејудицирања под условом: а) да јој је трасант непосредно послао чек, и б) да се ради о чеку на име или по наредби. ${ }^{23}$ Смисао наведеног изузетка огледа се у чињеници да овде спречавање опозива не би могло да испуни сврху убрзања циркулације, односно наплате чека, нити заштите поверења његовог законитог имаоца у правни привид. Уз то, у овом случају је ризик да ће банка извршити исплату противно пуноважном опозиву сразмерно мали, имајући у виду непосредно достављање чека банци и његово издавање на име, односно по наредби законитог имаоца. Из тих разлога, право на опозив чека у овим околностима треба допустити.

С друге стране, ако се правило Закона о чеку, по коме трасант може да опозове чек под условом да је протекао рок за његову презентацију на исплату, третира као диспозитивна норма, онда би уговором могло да се од ње одступи. Према томе, банка трасат и трасант би могли да уговоре право трасанта да опозове чек и пре његовог прејудицирања. Наведено тумачење не произлази недвосмислено из формулације релевантне одредбе српског закона. Напротив, начин прописивања овог услова више указује на то да је реч о императивној одредби, те да опозив чека, осим првонаведеног изузетка, није могућ пре протека рока за презентацију на исплату. ${ }^{24}$ Уосталом, чини се да у српској правној теорији преовлађује управо такво схватање. ${ }^{25}$ За разлику од тога, у праву Немачке постоји готово идентично правило о праву на опозив чека тек након прејудицирања као у српском Закону о чеку, ${ }^{26}$ али се сматра да је оно само диспозитивно, због чега банка трасат и трасант могу да уговоре пуноважност опозива и пре тог тренутка. ${ }^{27}$ Иста могућност постоји и у англосаксонском праву. ${ }^{28}$

Допуштање уговарања права на опозив чека и пре протека рока за презентацију на исплату не би утицало негативно на правни

23 ЗЧ, чл. 15, ст. 1, тач. 2. Трећи услов да изјава о опозиву мора да буде примљена пре него што је коначно извршена исплата чека представља општу претпоставку за сваки пуноважан опозив чека.

24 У прилог императивном карактеру норме говоре и казнене одредбе Закона о чеку. Вид. ЗЧ, чл. 26, ст. 1, тач. 2. Упор. С. Alter, 329.

25 И. Јанковец (1999), 734; М. С. Васиљевић, 518; упор.: С. Alter, 329 и 330.

26 Вид.: немачки Закон о чеку (Scheckgesetz из 1933. године са последњим изменама из 2015. године), Art. 32(1).

27 H.-P. Schwintowski, 338 и даље; G. Nobbe, 1678; S. Fandel, 326; Christian Koch, Der Zahlungsverkehr in der Bankpraxis, Wiesbaden 2012 2 , 404; F. Häuser, 462; M. Hakenberg, 1689; упор. S. Werner, 1027; Klaus J. Hopt, Baumbach/Hopt - Handelsgesetzbuch mit GmbH \& Co., Handelsklauseln, Bank- und Börsenrecht, Transportrecht (ohne Seerecht) (Hrsg. K. J. Hopt, et al.), München 2014 ${ }^{36}, 1904$.

28 М. С. Васиљевић, 518. 
положај банке трасата. Она свакако ни пре, ни после истека овог рока нема обавезу према законитом имаоцу да му исплати чек, већ такву обавезу дугује једино свом сауговарачу - трасанту (имаоцу текућег рачуна). Стога није спорно да би из угла банке трасата и трасанта овакву слободу уговарања требало дозволити. Истовремено, уговорено право на опозив чека пре прејудицирања не би нарочито угрожавало ни правни положај законитог имаоца. Наиме, чак и када би чек био пуноважно опозван пре протека рока за презентацију на исплату, законити ималац би тада још увек имао чековна потраживања против регресних чековних дужника. ${ }^{29} \mathrm{У}$ том погледу је његова заштита загарантована посебним правилима о чеку као хартији од вредности. Захваљујући томе, он би могао да остварује своје потраживање директно у извршном поступку, на основу протестованог чека као веродостојне исправе. ${ }^{30}$ Из објашњених упоредноправних схватања и изложених аргумената се закључује да би у српском праву, такође, требало дозволити уговарање права на опозив чека између банке трасата и трасанта у периоду пре истека рока за његову презентацију на исплату.

\section{2. Извршење исплате чека као крајњи рок за вршење права на опозив чека}

Трасант може да врши своје право на опозив чека најкасније до момента када банка трасат коначно исплати чек законитом имаоцу. ${ }^{31}$ Ово правило важи у сваком случају опозивања чека, мада као такво није јасно прописано српским Законом о чеку. Наиме, овај закон једино у изузетном случају опозивања чека на име или по наредби, који је непосредно послат банци трасату, прописује да право на опозив постоји под условом да банка још увек није извршила платни налог дат путем чека. ${ }^{32}$ Упркос томе, треба сматрати да се овај услов по аналогији примењује на пуноважност сваког опозива чека. Логика таквог тумачења почива на чињеници да право на опозив не може да се врши на штету банке трасата, која је савесно испунила своју уговорну обавезу извршења пуноважног платног налога трасанта. У супротном, када би се трасанту дозволило да опозове чек и након његове исплате, тиме би банци трасату накнадно била одузета могућност да своје трошкове извршеног плаћања накнади од имаоца текућег рачуна. То би доводило до апсурдног исхода, по коме би ри-

29 F. Häuser, 462; M. Hakenberg, 1689.

30 Закон о извршењу и обезбеђењу, Службени гласник РC, бр. 106/2015, чл. 52 , ст. 2 , тач. 1 .

31 S. Werner, 1027; H.-P. Schwintowski, 339; C. Koch, 404; F. Häuser, 463; G. Nobbe, 1679; J. Reynolds, 352.

32 ЗЧ, чл. 15 , ст. 1 , тач. 2. 
зик читаве трансакције био пребачен на банку трасата, иако је она у свему поступала савесно и у складу са уговором са трасантом (имаоцем текућег рачуна).

Трасантово право на опозив чека престаје само ако је исплата чека од стране банке трасата коначна. При том се исплата сматра коначном, када банка трасат више нема право да изврши њен повраћај у пређашње стање. ${ }^{33}$ Примера ради, банка трасат је коначно исплатила чек када је имаоцу предала одговарајући износ готовог новца, или када је коначно задужила трасантов текући рачун и пренела износ чековне своте на рачун банке законитог имаоца у безготовинском платном промету. ${ }^{34}$ За разлику од тога, све док банка трасат још увек може да спречи, односно обустави исплату чека, враћањем предузетих радњи у пређашње стање, трасант има право да опозове чек. ${ }^{35}$ Таква ситуација у Немачкој постоји у року од два дана од задужења текућег рачуна издаваоца чека, будући да је до тада банка трасат још увек овлашћена да сторнира извршени упис на рачун. ${ }^{36}$

У случају да опозив чека стигне банци трасату након што је она већ коначно извршила исплату, такав опозив неће производити правна дејства. При том је банка трасат дужна да свог клијента (имаоца текућег рачуна) обавести да његов опозив из тог разлога није пуноважан. ${ }^{37}$ У недостатку таквог обавештења трасанту може да буде проузрокована штета услед поуздања у успешну забрану исплате чека, коју би банка по правилима о уговорној одговорности била дужна да надокнади. ${ }^{38}$

\section{3. Самостална обавеза банке трасата да исплати чек законитом имаоцу као препрека за вршење права на опозив чека}

Начелно, банка трасат нема непосредну обавезу према законитом имаоцу да изврши исплату презентованог пуноважног чека. ${ }^{39}$ Штавише, у српском праву таква чековна обавеза не може ни да настане, с обзиром на то да је акцептирање чека од стране банке трасата изричито забрањено. Исто важи и за друге чековне радње, на основу којих би банка трасат стекла самосталну чековну обавезу према имаоцу чека (попут, авалирања чека). Међутим, неспорно је да банка трасат чак и у праву Србије може да прихвати непосредну оба-

33 Упор. М. Hakenberg, 1689.

34 Упор. С. Koch, 404.

35 Упор. Е. P. Ellinger, E. Lomnicka, C. V. M. Hare, 487.

36 Упор. S. Werner, 1028; C. Koch, 404; F. Häuser, 463; G. Nobbe, 1680.

37 G. Nobbe, 1680.

38 Ibid.

39 C. Alter, 329; J. Breslin, Banking Law, Dublin 2007², 201 и 202. 
везу према законитом имаоцу чека да ће извршити исплату по датом чеку, која је ванчековне природе (на пример, цертификовањем чека). Отуда се поставља питање, да ли трасант и након настанка самосталне (ванчековне) обавезе банке трасата према законитом имаоцу да исплати одређени чек, може да врши право на опозив тог чека. У англосаксонском праву се ово питање разматра из угла допуштености опозива цертификованих чекова ${ }^{40}$ док се у праву Немачке проширује на све чекове, код којих банка трасат гарантује исплату законитом имаоцу.

Када би се дозволило да трасант опозове чек, по коме је банка трасат већ стекла самосталну обавезу исплате према законитом имаоцу, таква ситуација би доводила банку у изразито неповољан положај. С једне стране, она услед опозива од стране трасанта не би имала право да одбије испуњење своје обавезе према законитом имаоцу, јер је та обавеза независна од њеног правног односа са имаоцем текућег рачуна. С друге стране, ако би банка трасат извршила исплату законитом имаоцу, она услед пуноважног опозива чека не би имала право да трошкове извршеног плаћања накнади задужењем трасантовог текућег рачуна. ${ }^{41}$ Из тог разлога се у упоредном праву сматра да трасант нема право да опозове чек у периоду док постоји самостална обавеза (гаранција) банке трасата према имаоцу чека да изврши исплату тог чека. ${ }^{42}$ Наравно да у том погледу опозив не би био дозвољен само до висине гарантованог износа чека. ${ }^{43}$

Нажалост, у српском праву постојање самосталне обавезе банке трасата према законитом имаоцу чека није прописано као препрека за вршење трасантовог права на опозив чека. Ипак, имајући у виду изложене аргументе, забрана опозива чека би у овом случају била оправдана и пожељна. У том погледу је у потпуности применљива аналогија са правилом о забрани опозива након коначне исплате чека од стране банке трасата. Као што трасант не може да опозове чек након његове коначне исплате од стране банке, из истих разлога не треба да има право на опозивање чека након настанка самосталне обавезе банке трасата према законитом имаоцу да изврши исплату чека. И једна и друга радња банке трасата се на тај начин одражавају на њену имовину, да она више не може да врши њихов повраћај у

40 J. Reynolds, 344 и даље; J. H. de V. Dijkman, 83 и даље.

41 Упор. J. H. de V. Dijkman, 95.

42 Benjamin Geva, Bank Collections and Payment transactions: Comparative study of legal aspects, Oxford 2001, 145; R. Cranston, 260; J. H. de V. Dijkman, 84; R. Herrera, 207.

43 Упор. М. Hakenberg, 1689. Једини изузетак од наведеног правила се у праву САД прихвата у ситуацији када је трасант у могућности да заједно с опозивом банци трасату достави и чек, како би она отказала дато цертификовање и тиме се ослободила своје обавезе према законитом имаоцу. Вид. J. Reynolds, 345. 
пређашње стање. Стога би опозивање чека и овде доводило до неоправданог преваљивања ризика плаћања на банку трасата, иако је она у датом случају поступала савесно и у интересу трасанта. Из тог разлога, по аналогији са забраном опозива чека након његове коначне исплате, треба сматрати да опозив у периоду док постоји самостална обавеза банке трасата према имаоцу чека да исплати чек, такође, није дозвољен.

\section{5. ИЗЈАВА О ОПОЗИВУ ЧЕКА}

Да би опозив чека био пуноважан, потребно је да постоји изјава о опозиву чека, која испуњава одређене услове. Ови услови се тичу: 5.1. даваоца изјаве; 5.2. адресата изјаве; 5.3. форме изјаве; 5.4. садржине изјаве; и 5.5. пријема изјаве.

\section{1. Давалац изјаве}

Изјаву о опозиву чека свакако може пуноважно да да̂ сам трасант као његов издавалац. Међутим, иако се на први поглед чини да само трасант може да врши право на опозив чека, у упоредном праву се у одређеним ситуацијама и другим лицима признаје право да то учине у његово име. Наравно да је изјава о опозиву чека сваког лица, које је овлашћено на заступање трасанта у овом погледу, такође, пуноважна, тако да производи правна дејства непосредно за трасанта као заступаног. ${ }^{44}$ Уз то, право да опозову чек у име трасанта имају и лица, која иначе нису овлашћена да га заступају, али јесу овлашћена да располажу средствима са конкретног текућег рачуна, која треба да служе као покриће за исплату датог чека. Према томе, у случају да се текући рачун води као заједнички рачун с два или више пуноправна имаоца рачуна, сваки од тих ималаца рачуна је овлашћен да опозове чек, који је издао неки други ималац. ${ }^{45}$ Исто важи и за друга лица која су овлашћена да располажу средствима са текућег рачуна издаваоца чека. Разлог се огледа у чињеници да је опозив усмерен ка спречавању извршења платног налога, чије трошкове би банка трасат имала право да накнади из расположивих средстава, односно средстава кредита у прекорачењу текућег рачуна. Отуда се допуштањем да и друга лица овлашћена за располагање средствима са текућег рачуна откажу чек, који је издао ималац тог рачуна, омогућава адекватна заштита њихових интереса у вези са покрићем на рачуну. ${ }^{46}$

44 M. Hakenberg, 1689.

45 E. P. Ellinger, E. Lomnicka, C. V. M. Hare, 484; yпор. M. Hakenberg, 1689.

46 Уз то, у немачком праву опозив чека може да буде пуноважан чак и када потиче од неовлашћеног лица, под условом да је банка трасат сазнала за околности, 


\section{2. Адресат изјаве}

Неспорно је да изјава о опозиву чека мора да буде упућена банци трасату, на коју је дати чек вучен. Међутим, банке у пракси по правилу послују преко својих бројних филијала (огранака). Отуда, треба сматрати је за пуноважан опозив чека довољно достављање изјаве о опозиву филијали банке трасата, која води дати текући рачун, ${ }^{47}$ тако да се њено сазнање да је исплата чека услед опозива забрањена приписује читавој банци, односно свим осталим филијалама. ${ }^{48}$ Ипак, да би описане последице наступиле, неопходно је да филијала банке трасата, која води одговарајући текући рачун издаваоца чека, заиста сазна за опозив. Стога, ако изјава о опозиву чека буде достављена другој филијали банке трасата, она је дужна да је без одлагања проследи филијали која води текући рачун трасанта..$^{49}$ При том, евентуално кашњење у саопштавању опозива одговарајућој филијали банке трасата, због достављања изјаве другој (погрешној) филијали, пада на терет трасанта, односно даваоца те изјаве..$^{50}$ Коначно, да би изјава о опозиву била пуноважна, она мора да буде саопштена запосленом у одговарајућој филијали банке трасата, од кога се може очекивати да поступи у складу са опозивом. ${ }^{51}$ Ипак, није нужно да тај запослени има заступничка овлашћења у вези са плаћањем конкретног (опозваног) чека. ${ }^{52}$

\section{3. Форма изјаве}

У упоредном праву је неспорно да изјава о опозиву чека не мора да испуњава никакве посебне захтеве форме. ${ }^{53}$ Отуда, чек може да се опозове и усмено, као и телефоном, мејлом или факсом. ${ }^{54}$ Штавише, за пуноважност опозива није неопходно да банка трасат потврди пријем ове изјаве. ${ }^{55}$ Ипак, у праву САД је прописано да усмени

које би довеле до опозива чека непосредно од стране трасанта када би му биле познате. Вид. М. Hakenberg, 1689; F. Häuser, 461.

47 R. Cranston, 260; E. P. Ellinger, E. Lomnicka, C. V. M. Hare, 485.

48 J. Reynolds, 352.

49 F. Häuser, 461; G. Nobbe, 1679.

50 M. Hakenberg, 1689.

51 E. P. Ellinger, E. Lomnicka, C. V. M. Hare, 487; упор. В. Geva, 145. Из тог разлога, давање изјаве о опозиву запосленом који ради на телефонској централи банке трасата не би производило дејства пуноважног опозива.

52 F. Häuser, 461.

53 C. Alter, 330; C. Koch, 403; M. Hakenberg, 1689; E. P. Ellinger, E. Lomnicka, C. V. M. Hare, 486.

54 M. Hakenberg, 1689; C. Koch, 403; E. P. Ellinger, E. Lomnicka, C. V. M. Hare, 486; G. Nobbe, 1679; упор. J. Reynolds, 348.

55 G. Nobbe, 1679. 
опозив чека производи правна дејства само ако је у кратком року потврђен и писменом изјавом његовог даваоца. Осим тога, уговором између банке трасата и имаоца текућег рачуна се редовно предвиђају додатни захтеви у погледу форме опозива као услова његове пуноважности. Такве уговорне одредбе су у сваком случају корисне, јер омогућавају спречавање злоупотреба, које би могле да настану услед потпуне неформалности. У српском праву форма изјаве о опозиву чека није прописана, тако да у том погледу треба применити основно начело неформалности правних послова. ${ }^{56}$ Међутим, због проблема доказивања и ризика злоупотреба, ово питање би требало додатно уредити уговором између банке и имаоца текућег рачуна.

\section{4. Садржина изјаве}

Садржина изјаве о опозиву чека, такође, није ближе прописана. Отуда, она може да буде прецизирана уговором између банке трасата и трасанта. Независно од тога, неспорно је да у оквиру изјаве о опозиву мора да се нагласи да се њоме забрањује исплата одређеног чека. Према томе, чак и када то није уговорено, подразумева се да трасант у опозиву мора јасно да идентификује чек који се опозива. ${ }^{57}$ То може да се учини преко навођења елемената попут, имена трасанта, трасата, ремитента, броја и датума чека, износа, броја текућег рачуна и сврхе плаћања. ${ }^{58}$ Опис чека у опозиву треба да буде у разумној мери тачан, ${ }^{59}$ тако да банка с разумним степеном сигурности може да утврди о ком чеку се ради. ${ }^{60}$ Другим речима, иако је неки детаљ у вези с описом чека нетачан (на пример, чековна свота), то не утиче на пуноважност опозива, под условом да је на основу осталих података јасно који је чек у питању. ${ }^{61}$

Садржина изјаве воље којом се опозива чек не сме да буде двосмислена. ${ }^{62}$ У ситуацији када је опозив двосмислен или у поје-

56 Супротно вид. И. Јанковец (1999), 734; М. С. Васиљевић, 518.

57 B. Geva, 146; S. R. Magnet, 299.

58 R. Herrera, 208; D. Benjamin Beard, „Effectuating the Customer's Right to Stop Payment of a Check: The Forgotten Section 4-401“, The Wayne Law Review Vol. 37, 1991, 1845.

59 E. P. Ellinger, E. Lomnicka, R. Hooley (2002), 383 фн. 111.

60 В. Geva, 133.

61 Наведено правило је више одговарало ранијој мануелној обради чекова и њихових опозива. За разлику од тога, данас се чекови, као и опозиви, обрађују уз помоћ рачунарске технологије. Имајући у виду да компјутерски програм теже може да установи разлику између ситне и крупне нетачности у опису чека, то ствара ризик занемаривања опозива, који је само у неком незнатном детаљу нетачан (на пример, уместо 1.865,43 динара, колико заиста износи чековна свота, наводи $1.865,45$ динара). Више вид. R. Herrera, 206 и даље; S. R. Magnet, 301.

62 B. Geva, 146; E. P. Ellinger, E. Lomnicka, C. V. M. Hare, 485; S. R. Magnet, 298 и 299; J. Reynolds, 346. 
диним детаљима нетачно описује чек, банка трасат би у случају сумње око утврђивања стварне намере клијента требало да од њега затражи појашњење. ${ }^{63}$ Насупрот томе, ако је банка поступала савесно, односно у разумном уверењу да то одговара намери клијента, она у односу с трасантом неће сносити негативне последице исплате, односно неисплате одређеног чека. ${ }^{64}$

\section{5. Пријем изјаве}

У складу с општим правилима облигационог права, изјава о опозиву чека производи правна дејства од момента пријема од стране филијале банке трасата, која води одговарајући текући рачун. ${ }^{65}$ Ипак, од наведеног теоријског правила се у пракси допушта један оправдан изузетак. Сходно томе, опозив ће производити правна дејства само ако је банка трасат имала разумну могућност да поступи у складу са њим, ${ }^{66}$ односно ако би неодложном обрадом примљеног опозива уопште могла да спречи исплату чека у редовном току пословања. ${ }^{67}$ Насупрот томе, она није дужна да предузима било какве ванредне мере, како би онемогућила исплату конкретног чека, на који се опозив односи. ${ }^{6}{ }^{6}$ Стога, у ситуацији када банка трасат у моменту пријема изјаве о опозиву не може једноставно да прекине покренут аутоматизован поступак исплате чека, сматра се да опозив не производи намеравана правна дејства, упркос томе што је стигао код трасата пре дефинитивног извршења платног налога. ${ }^{69}$

Из истог разлога се банци трасату толерише кратко време од момента пријема изјаве о опозиву, које јој је потребно да прилагоди своје поступање забрани исплате чека. Реч је о времену које је према редовном току ствари неопходно да би запослени коме је опозив саопштен о томе обавестио запослене који раде на пословима исплате чекова (на пример, шалтерске службенике). ${ }^{70}$ У ситуацији када се чек поднесе на наплату у том кратком периоду, непосредно након опозива, сматра се да банка трасат уредно испуњава платни налог исплатом чека упркос чињеници да је, строго посматрано, већ примила његов опозив.

63 E. P. Ellinger, E. Lomnicka, C. V. M. Hare, 485 фн. 272.

64 Ibid., 485.

65 Ibid., 487.

66 R. Cranston, 260.

67 F. Häuser, 461; S. Werner, 1028; H.-P. Schwintowski, 339; C. Koch, 403; M. Hakenberg, 1689; G. Nobbe, 1679 и 1680.

68 S. Werner, 1028; G. Nobbe, 1680.

69 Упор. S. Werner, 1028.

70 E. P. Ellinger, E. Lomnicka, C. V. M. Hare, 487. 


\section{6. РОК ВАЖЕЬА ОПОЗИВА}

У упоредном праву се као посебан проблем јавља питање рока важења опозива. С једне стране, у праву САД је изричито прописано да опозив чека важи само за период од шест месеци, након чега може да буде обновљен за наредних шест месеци. ${ }^{71} \mathrm{C}$ друге стране, у немачком праву, упркос непостојању сличног временског ограничења опозива чека у самом закону, банке са клијентима често уговарају да евентуални опозив важи шест месеци од тренутка пријема одговарајуће изјаве воље трасанта. ${ }^{72}$ Након истека овог периода сматраће се да чек није опозван, па ће банка моћи пуноважно да изврши плаћање из покрића на текућем рачуну трасанта. На тај начин се ограничава број опозива чекова, о којима банка мора да води рачуна у свом редовном пословању. ${ }^{73}$ У случају да трасант и након истека овог рока жели да спречи исплату чека, он би морао да „обнови“ опозив, ${ }^{74}$ тако што би поново упутио одговарајућу изјаву воље банци трасату. ${ }^{75}$ При том, за „услугу“ обнављања опозива банке клијентима редовно наплаћују одређену накнаду (провизију). ${ }^{76}$

Описанапраксајепредмет оправдане критике уупоредноправној теорији. ${ }^{77}$ У том погледу поједини аутори истичу да једном опозван платни налог, коме су одузета правна дејства, не може да „оживи“ након протека одређеног рока. ${ }^{78}$ Напротив, опозван платни налог по основу чека је дефинитивно угашен, а клијент, ако жели, једино може да да̂ банци нов налог са истом садржином. Изложеном аргументу банке приговарају да је у пракси немогуће спровести бесконачно дуго поштовање једном датог опозива чека. Наиме, банке тврде да не постоје одговарајуће техничке претпоставке за уважавање забране исплате чека, која би важила за сва времена. ${ }^{79}$

Чини се да изложена супротстављена становишта могу да се помире једино другачијим схватањем правне природе опозива чека. Када се опозив схвати као налог којим се забрањује извршење платног налога датог путем чека (тзв. противналог), онда његово извршење, као и код сваког другог налога, може да буде ограниче-

71 R. J. Mann, 15.

S. Fandel, 326; H.-P. Schwintowski, 341; F. Häuser, 461; G. Nobbe, 1680.

F. Häuser, 461; G. Nobbe, 1680.

74

R. J. Mann, 15.

75 G. Nobbe, 1680.

76 S. Fandel, 326; G. Nobbe, 1680 и 1681.

77 H.-P. Schwintowski, 341.

78 S. Fandel, 326.

79 Упор.: R. J. Mann, 15. 
но одређеним роком. У случају усвајања овог схватања у српском праву, банка трасат би у уговору са клијентом могла да предвиди да ће налог којим се забрањује исплата чека („опозив чека“) производити правна дејства у року од, примера ради, шест месеци, након чега банка више неће бити у обавези да одбије исплату, већ ће моћи да испуни платни налог из чека. Међутим, чак и када би се прихватило наведено тумачење, остаје спорно право банке да за опозив чека наплаћује посебну накнаду (провизију). Имајући у виду да опозив периодично мора да се обнавља ако трасант не жели да банка из покрића на његовом платном рачуну исплати чек, таква наплата провизије би водила теоријски бесконачној „обавези“ клијента да врши плаћања банци по овом основу. ${ }^{80}$ Ипак, упркос изложеним недостацима право банке да наплати провизију за опозив чека (као и за његово обнављање) у упоредном праву опстаје.

\section{7. ПРАВНЕ ПОСЛЕДИЦЕ ПУНОВАЖНОГ ОПОЗИВА ЧЕКА}

Банка трасат на основу пуноважног опозива има обавезу према трасанту да одбије исплату чека законитом имаоцу. ${ }^{81}$ При том, у немачком праву банке третирају обраду опозива чека као додатну услугу клијенту, за коју наплаћују одређену накнаду. ${ }^{82}$ Таква пракса се оправдава чињеницом да је трасант давањем платног налога путем чека и његовим стављањем у правни промет омогућио покретање поступка наплате од стране законитог имаоца, па проузрокује додатне трошкове банци ако је опозивањем чека обавеже да такву наплату спречи. ${ }^{83}$ Исто схватање би требало прихватити и у српском праву. Уосталом, оно је у складу и с општим правилима комунитарног права платних услуга, по којима банка, такође, има право на посебну накнаду за опозив платног налога. ${ }^{84}$

\section{1. Последице поступања банке трасата у складу с опозивом}

Банка трасат поступа у складу са пуноважним опозивом ако одбије исплату чека његовом имаоцу. У том случају, ималац чека

80 S. Fandel, 326.

81 K. J. Hopt, 1904; E. P. Ellinger, E. Lomnicka, R. Hooley (2002), 382; H.-P. Schwintowski, 340; M. Hakenberg, 1689; J. Reynolds, 342.

82 G. Nobbe, 1680 и 1681.

83 G. Nobbe, 1681.

84 Directive (EU) 2015/2366 of the European Parliament and of the Council of 25 November 2015 on payment services in the internal market, amending Directives 2002/65/ EC, 2009/110/EC and 2013/36/EU and Regulation (EU) No 1093/2010, and repealing Directive 2007/64/EC, Official Journal L 337, 23. 12. 2015, Art. 80(5). 
једино може да захтева плаћање од регресних чековних дужника, под претпоставком да чек још увек није прејудициран, односно од дужника из основног посла, који му је чек издао или пренео као начин испуњења новчане обавезе. Приликом одбијања исплате чека банка трасат је према свом клијенту (трасанту) дужна да обавести имаоца о чињеници да је опозив чека разлог тог одбијања. ${ }^{85} \mathrm{y}$ супротном би ималац чека по правилу закључио да је трасант неспособан за плаћање, што би могло негативно да се одрази на његово пословање. ${ }^{86}$ Из тог разлога, банка трасат која пропусти да информише имаоца чека о опозиву, одговара за евентуалну штету проузроковану трасанту по правилима уговорне одговорности. ${ }^{87}$

\section{2. Последице исплате чека од стране банке трасата након пуноважног опозива}

Када банка исплати чек упркос пуноважном опозиву, сматра се да није поступала по налогу клијента (трасанта) ${ }^{88}$ па по том основу нема право да од њега захтева накнаду трошкова. ${ }^{89}$ У случају да је банка на основу исплате опозваног чека задужила текући рачун трасанта, она мора да изврши повраћај рачуна у пређашње стање, као и да накнади трасанту евентуалну другу штету због повреде налога. ${ }^{90}$ То, међутим, не значи да ће банка у коначном исходу поднети терет исплате опозваног чека из сопствене имовине. Напротив, она под одређеним условима може да захтева накнаду од имаоца чека по правилима о стицању без основа. ${ }^{91}$ Наведени захтев против имаоца чека постоји само ако је он у моменту исплате био несавестан, јер је знао да је чек опозван. ${ }^{22}$ У супротном, ако ималац чека у том тренутку није знао за опозив, пријем исплате од банке трасата као налогопримца (помоћника у испуњењу) дужника из основног посла за њега

85 H.-P. Schwintowski, 340; F. Häuser, 462; M. Hakenberg, 1689; G. Nobbe, 1680; K. J. Норt, 1904. Податак о опозиву чека банка трасат треба да наведе на самом чеку ако ималац то захтева.

86 G. Nobbe, 1680.

87 H.-P. Schwintowski, 340; F. Häuser, 462; G. Nobbe, 1680.

88 Упор.: D. В. Beard, 1828.

89 K. J. Hopt, 1904; F. Häuser, 509; G. Nobbe, 1680; M. Hakenberg, 1690; B. Geva, 146; И. Јанковец (1999), 734; упор.: F. van Look y: Carsten Peter Claussen, Bank- und Börsenrecht für Studium und Praxis, München 2008 ${ }^{4}$, 193; E. P. Ellinger, E. Lomnicka, C. V. M. Hare, 484 и 489.

90 G. Nobbe, 1680; S. Fandel, 327; M. Hakenberg, 1690; R. J. Mann, 15 и 16; В. Geva, 133 и 146; J. Breslin, 200; S. R. Magnet, 311; упор. Е. P. Ellinger, E. Lomnicka, C. V. M. Hare, 489; C. Alter, 330; о проблему доказивања штете у праву САД вид. D. В. Beard, 1819 и даље.

91 C. Alter, 330; J. Breslin, 200.

92 F. Häuser, 509; M. Hakenberg, 1690; K. J. Hopt, 1904. 
представља испуњење новчане обавезе поводом које је чек издат. ${ }^{93}$ Према томе, савестан ималац чека није обогаћен, јер је преносом новчаних средстава од стране банке трасата његова имовина, додуше, увећана, али је истовремено и умањена престанком потраживања према трасанту из основног посла. Стога, банка од њега не може да тражи накнаду из неоснованог обогаћења.

У ситуацији када банка не може да накнади исплаћени чековни износ од имаоца чека, она ће то по правилу моћи да оствари против трасанта. ${ }^{94}$ Наиме, ако исплата чека законитом имаоцу од стране банке трасата доводи до измирења обавезе трасанта у основном послу, реч је о испуњењу туђе обавезе од стране трећег лица. ${ }^{95}$ Према општим правилима облигационог права, законити ималац чека као поверилац из основног посла може да прими испуњење од трећег лица чак и против воље дужника (издаваоца чека), ${ }^{96}$ што значи чак и када је чек опозван. ${ }^{97}$ На основу такве исплате долази до персоналне суброгације банке трасата у права повериоца према трасанту као дужнику из основног посла. ${ }^{98} \mathrm{C}$ обзиром на то да банка ступа у правни положај повериоца из основног посла, против њеног захтева трасант, додуше, може да истиче све приговоре које је имао у односу са претходним повериоцем и који су евентуално представљали оправдан разлог за опозив чека.

Правни захтев банке трасата стечен персоналном суброгацијом и правни захтеви трасанта за повраћај рачуна у пређашње стање и накнаду штете због неовлашћеног задужења исплатом опозваног чека су узајамна, доспела, новчана потраживања, која захваљујући томе могу да се пребијају. Отуда ће банка у случају персоналне суброгације против захтева клијента моћи да истакне приговор компензације и тиме, барем делимично, избегне повраћај задуженог текућег рачуна у пређашње стање. ${ }^{99}$

93 M. Hakenberg, 1690.

94 M. Hakenberg, 1690; K. J. Hopt, 1904.

95 B. Geva, 146; E. P. Ellinger, E. Lomnicka, C. V. M. Hare, 489; F. Häuser, 509; S. R. Magnet, 314; J. Reynolds, 363.

96 И. Јанковец, Правни аспекти новчаних обавеза, Београд 2003, 25.

97 Закон о облигационим односима - ЗОО, Службени лист СФРЈ, бр. 29/78, 39/85, 45/89, 57/89, Службени лист СРЈ, бр. 31/93, Службени лист СЦГ, бр. 1/2003, чл. 296 , ст. 4.

98 3ОО, чл. 300; В. Geva, 146; R. J. Mann, 16; D. В. Beard, 1829 и 1835; R. Herrera, 208 фн. 19; J. Reynolds, 365. Законска персонална суброгација се догађа на основу правног интереса банке трасата да не изврши такву исплату за свој рачун, већ да стекне право регреса против дужника (трасанта).

99 Упор. R. J. Mann, 16; E. P. Ellinger, E. Lomnicka, R. Hooley (2002), 387. 


\section{8. ЗАКЉУЧАК}

Опозив чека је значајан правни институт који омогућава спречавање извршења пуноважно датог платног налога путем чека из средстава на текућем рачуну издаваоца. У складу са упоредноправним схватањима у развијеним земљама, опозив чека би и у праву Србије требало тумачити као противналог, којим се забрањује извршење претходно пуноважно датог платног налога, а не као опозивање платног налога, којим се он дефинитивно гаси. Тиме би се омогућило уговарање крајњег рока важења датог опозива између банке трасата и трасанта, након чијег протека би банка поново имала право да исплати презентован чек из покрића на трасантовом текућем рачуну. Уз то, опозивање чека у српском праву треба на уговорној основи дозволити и пре, а не искључиво после протека рока за презентацију на исплату. Коначно, моменат наступања правних дејстава опозива чека треба везивати за тренутак пријема изјаве о опозиву од стране филијале банке, која води текући рачун издаваоца, али само под условом да банка неодложном обрадом таквог опозива уопште може да спречи исплату чека у редовном току свог пословања.

\section{ЛИТЕРАТУРA (REFERENCES)}

Alter, C., Droit bancaire général, Bruxelles 2010.

Assies, P. H. et al. (Hrsg.), Handbuch des Fachanwalts: Bank-und Kapitalmarktrecht, Köln $2015^{4}$.

Бартош, М., Антонијевић, З., Јовановић, В., Менично и чековно право, Београд 1974. (Bartoš, M., Antonijević, Z., Jovanović, V., Menično i čekovno pravo, Beograd 1974)

Beard, D. B., „Effectuating the Customer's Right to Stop Payment of a Check: The Forgotten Section 4-401", The Wayne Law Review Vol. 37, 1991.

Breslin, J., Banking Law, Second Edition, Dublin 2007.

Claussen, C. P., Bank-und Börsenrecht für Studium und Praxis, München $2008^{4}$.

Cranston, R., Principles of Banking Law, Oxford $2005^{2}$.

de V. Dijkman J. H., „Countermand of a Certified Cheque“, The South African Law Journal Vol. 105, 1988.

Ellinger, E. P., Lomnicka E., Hare C. V. M., Ellinger's Modern Banking Law, Oxford 2011 5 .

Fandel, S., Handbuch des Fachanwalts: Bank- und Kapitalmarktrecht (Hrsg.P. H. Assies et al.), Köln 2015 . 
Geva, B., Bank Collections and Payment transactions: Comparative study of legal aspects, Oxford 2001.

Hakenberg, M., Ebenroth/Boujong/Joost/Strohn - Handelsgesetzbuch: Band 2 - $\S 343-475 h$ : Transportrecht, Bank- und Börsenrecht (Hrsg. D. Joost, L. Strohn), München 2015.

Häuser, F., Münchener Kommentar zum Handelsgesetzbuch - Band 6: Bankvertragsrecht (Hrsg. K. Schmidt), München 2014³.

Herrera, R., „Computerized Check Processing De Minimis Errors in Check Description on Stop Payment Orders", Computer/Law Journal Vol. IX, 1989.

Hopt, K. J., Baumbach/Hopt - Handelsgesetzbuch mit GmbH \& Co., Handelsklauseln, Bank- und Börsenrecht, Transportrecht (ohne Seerecht) (Hrsg.K. J. Hopt, et al.), München 2014 ${ }^{36}$.

Јанковец, И., Правни аспекти новчаних обавеза, Београд 2003. (Jankovec, I., Pravni aspekti novčanih obaveza, Beograd 2003)

Јанковец, И., Привредно право, Београд $1999^{4}$. (Jankovec, I., Privredno pravo, Beograd 1999 $)$

Joost, D., Strohn, L. (Hrsg.), Ebenroth/Boujong/Joost/Strohn Handelsgesetzbuch: Band $2-\S \S 343-475$ h: Transportrecht, Bankund Börsenrecht, München 2015.

Koch, C., Der Zahlungsverkehr in der Bankpraxis, Wiesbaden $2012^{2}$.

Kümpel, S., Wittig, A. (Hrsg.), Bank- und Kapitalmarktrecht, Köln $2011^{4}$.

Magnet, S. R., „Inaccurate or Ambiguous Countermand and Payment over Countermand“, Canadian Business Law Journal Vol. 4, 1979/80.

Nobbe, G., Bankrechts-Handbuch - Band I (Hrsg. H. Schimansky, H.-J. Bunte, H.-J. Lwowski), München 2011

Reynolds, J., „Countermand of Cheques“, U. B. C. Law Review Vol. 15, No. 2/1981.

Schimansky, H., Bunte, H.-J., Lwowski, H.-J. (Hrsg.), BankrechtsHandbuch - Band I, München 2011 ${ }^{4}$.

Schmidt, K. (Hrsg.), Münchener Kommentar zum Handelsgesetzbuch Band 6: Bankvertragsrecht, München 2014 ${ }^{3}$.

Васиљевић, М. С., Трговинско право, Београд $2014^{14}$. (Vasiljević, М. S., Trgovinsko pravo, Beograd 2014 ${ }^{14}$ )

Werner, S., Bank- und Kapitalmarktrecht (Hrsg. S. Kümpel, A. Wittig), Köln 2011 . 
Mirjana Radović, PhD, LL.M. (Humboldt)

Assistant Professor

University of Belgrade, Faculty of Law

\title{
COUNTERMAND OF A CHEQUE
}

\begin{abstract}
Summary
In this paper the author explores legal aspects of countermanding cheques. The first part of the paper explains the notion, legal significance and legal nature of stopping payment of cheques. The second part of the paper deals with the right to countermand payment of cheques and the requirements for exercising this right. In this respect, the author analyses effects of an expired deadline for cheque presentation, executed payment by the drawee bank, as well as the duty of the drawee bank to pay the cheque towards its holder, on the drawer's right to stop payment. Thereafter, the main characteristics of a countermand instruction are explained, with regard to: the persons authorised to give and receive this instruction, its form, contents and legal effects. The next part of the paper explains the comparative legal practice of limiting the period in which countermand of a cheque remains effective and explores its suitability for the Serbian law. Finally, the last part of the paper contains an in depth analysis of legal consequences in case of an effective stop payment order, especially in connection to the rights and obligations of the drawee bank.
\end{abstract}

Key words: Countermand. - Stop payment order. - Cheque. - Current Account.

Article history Received: 16. 4. 2016. Accepted: 16. 5. 2016. 